\title{
COMPARATIVE STUDY OF PROGRESSIVE COLLAPSE ANALYSIS OF FLAT SLAB BUILDING WITH AND WITHOUT SHEAR WALL
}

\author{
Divya $\mathbf{N}^{1}$, Gururaja B ${ }^{2}$, R Sridhar ${ }^{3}$ \\ ${ }^{I}$ PG Student, Civil Engg Department, Nagarjuna Collage of Engineering and Technology, Karnataka, India \\ ${ }^{2}$ Assistant Professor, Civil Engg Department, SJB Institute of Technology, Karnataka, India \\ ${ }^{3}$ Associate Professor, Civil Engg Department, Nagarjuna Collage of Engineering and Technology, Karnataka, India
}

\begin{abstract}
The progressive collapse of building occurs when one or more vertical load carrying structural elements like columns are removed. Once a column is removed due to an extreme loads generated either by natural hazard such as earthquake or by manmade like gas explosions, terrorist attacks, impact by vehicles etc. the weight of the structure transfers to neighboring columns in the structure. The present analytical study investigates failure criteria and potential of structural collapse of irregular R.C frame building having flat slab with and without shear wall. The column and shear wall has been removed at three different identified locations and spread of damage is evaluated. The progressive collapse study has been done for the each case by removing shear wall and column at identified critical locations as per GSA (2003) guidelines. Static analysis is performed using structural analysis program ETABS nonlinear version 9.7.4. For each case the results have been taken in terms of demand capacity ratio (DCR) at critical sections and thus, the structure has been assessed for it's susceptible to progressive collapse. The results showed existence of shear wall in the building makes it resistive to progressive collapse under loss of vertical load bearing element by providing sufficient stiffness and load paths for gravity loads.
\end{abstract}

KeyWords: Column removal, linear static analysis, Progressive collapse, Demand Capacity Ratio (DCR), Flat slab, Shear wall

\section{INTRODUCTION}

This present study focused on the behavior of the structure having flat slab with or without shear wall under progressive collapse. Flat slab is defined as a reinforced concrete slab that generally does not have beams and girders and the loads are exchanged specifically to the columns..Flat slab system has been widely adopted as a floor system in building construction. The flat slab panel may be divided into two strips; they are column strip and middle strip. Every structure contains huge bending moment and vertical forces happen in a zone of supports. This gives an extremely proficient structure. This is more satisfactory idea to many designers or originators. In present day, irregular layouts are becoming normal. Instantly, the Indian standard codes give the guidelines for design of flat slabs. As an earthquake safe framework, the utilization of shear wall is one of the potential alternatives. Shear walls are vertical components of the horizontal force opposing system. Shear walls are built to counter fort the impacts of lateral load acting a structure. Progressive collapse is defined as the spread of an initial local failure from element to element and which leads to the partial collapse or complete collapse due to an extreme loads generated either by the natural hazard(ex: Earthquake) or by manmade (ex: gas Explosions, Terrorist attacks, Impact by vehicles etc)[10].

The importance of design that can control progressive collapse was acknowledged in the recent decades due to several failures of buildings around the world caused by terrorist attacks or accidental gas explosions. The first progressive collapse regulatory documents followed the partial collapse of the "Ronan point" residential apartment building (London, 1968) due to a gas explosion from the $18^{\text {th }}$ storey and were included into the British standards. There have been some other examples of progressive collapse such as that of the "Alfred P. Murrah Federal building" (Oklahoma, 1995) due to terrorist attacks, of the "World Trade Centre" (New York, 2001).Where both towers completely destroyed. There are two different modes in progressive collapse mechanism. The first mode of progressive collapse mechanism determined by releasing support of the structure that to spreading failure to the above members of the structure.

The second mode of progressive of progressive collapse mechanism is demonstrated by failure at height levels of the structure causes debris loads which trigger sovereignty mechanism. Here the Flat slabs are structures without beams, hence the second mode of mechanism induces more dead weights on long spans of flat slab exceeding its capacities. If the shear walls are present the distribution of load paths would increase making the system stiffer against gravity loads under loss of any vertical load carrying member. Hence this present study gains its scope of understanding the potentials of Flat slab building with and without shear wall and comparing their susceptibility with respect to column DCR values and spread of collapse area. 


\subsection{Flat Slab System [12]}

\subsection{Shear Wall}

Shear wall is a vertical plate like reinforced concrete wall start from the footing level which is continuous throughout the structure height. Shear walls are incorporated in the building to resist lateral forces like wind or earthquake forces that are produced in the plane of wall. The thickness of shear wall varies from $150 \mathrm{~mm}$ to $400 \mathrm{~mm}$.

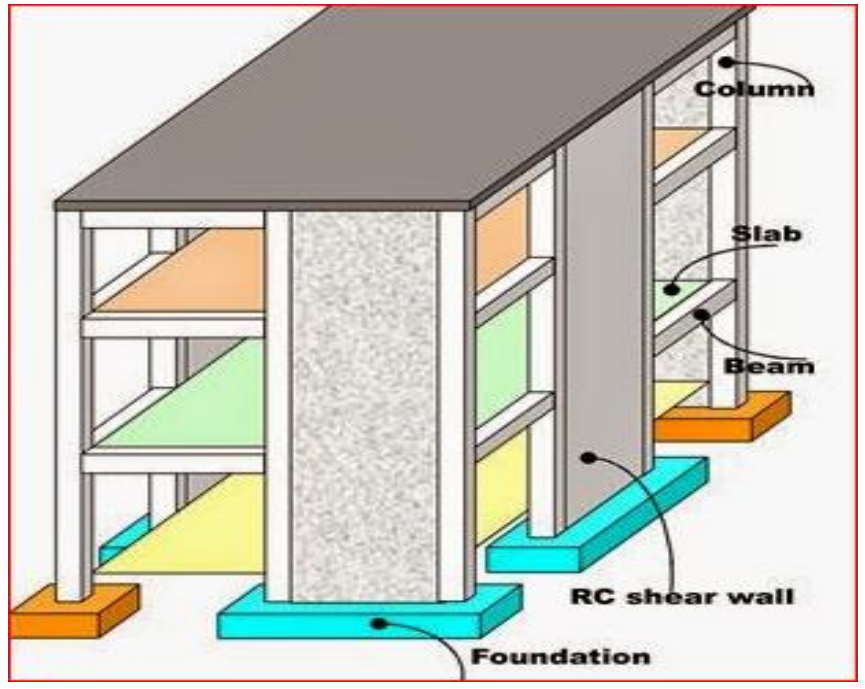

Fig -1: Shear wall building

When shear walls are designed properly and it can oppose the horizontally acting forces.

Various types of shear walls:

langed cantilever shear walls

oupled shear wall

hear walls with openings

ox type wall system

antilever shear wall

Advantages of shear walls:

Properly designed and developed shear wall structures have indicated great execution in past earthquakes.

Shear wall structures are a most mainstream decision in numerous quake inclined nations like Chile, USA, and New Zealand.

Shear walls are anything but difficult to develop, in light of the fact that detailing of reinforcement is generally straight and in this way actualized effortlessly at site.

Shear walls are most proficient as far as development expense.

\section{MODELLING AND DESIGN}

configuration of structure

The following two models have been created by using ETABS.

Model-1: Flat slab without shear wall

Model-2: Flat slab with shear wall

\subsection{Material Property}

The materials are considered for this study is M25 grade of concrete and $\mathrm{Fe} 415$ steel for all two models.
The element type is given as shell in flat slab structures

\subsection{Description Of Model-1}

Type of plan: Irregular

Each panel dimension: (8000x8000) mm

Number of storey : 10

Column size: $(900 x 900) \mathrm{mm}$

Edge beam size: $(300 \times 900) \mathrm{mm}$

Floor to floor height:3.6m(similar floors): $4 \mathrm{~m}$ (base floors)

Total height of the building: $36.4 \mathrm{~m}$

Slab thickness : $300 \mathrm{~mm}$

Loading:

a) Live load roof : $1.5 \mathrm{KN} \backslash \mathrm{m}^{2}$

Live load : $4 \mathrm{KN} \backslash \mathrm{m}^{2}$

b) Dead load roof : $3 \mathrm{KN} \backslash \mathrm{m}^{2}$

Other floors: $2.7 \mathrm{KN} \backslash \mathrm{m}^{2}$

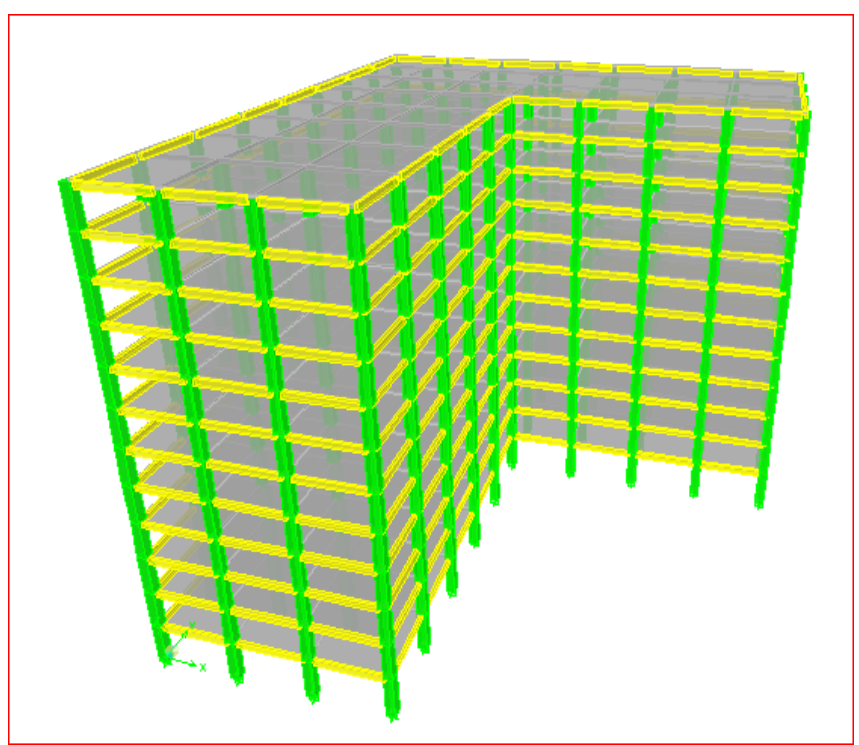

Fig-2: 3D model of flat plate without shear wall

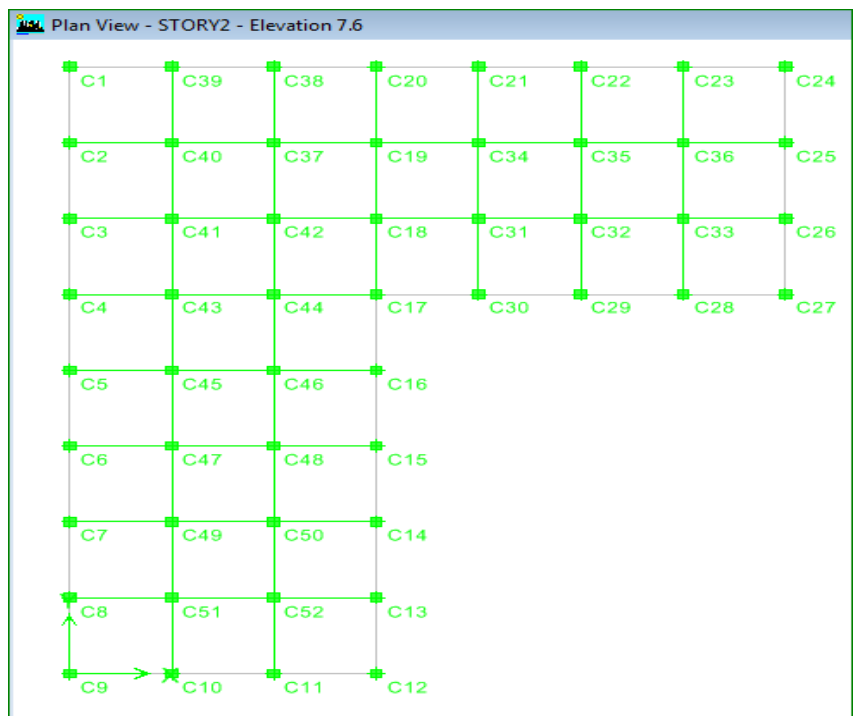

Fig-3: Plan view of Flat slab without shear wall (Model I) 


\subsection{Description Of Model-2}

All parameters except mentioned below are same as that of model-1

1) Shear wall thickness : $300 \mathrm{~mm}$

2) Edge beam size $:(400 \times 900) \mathrm{mm}$

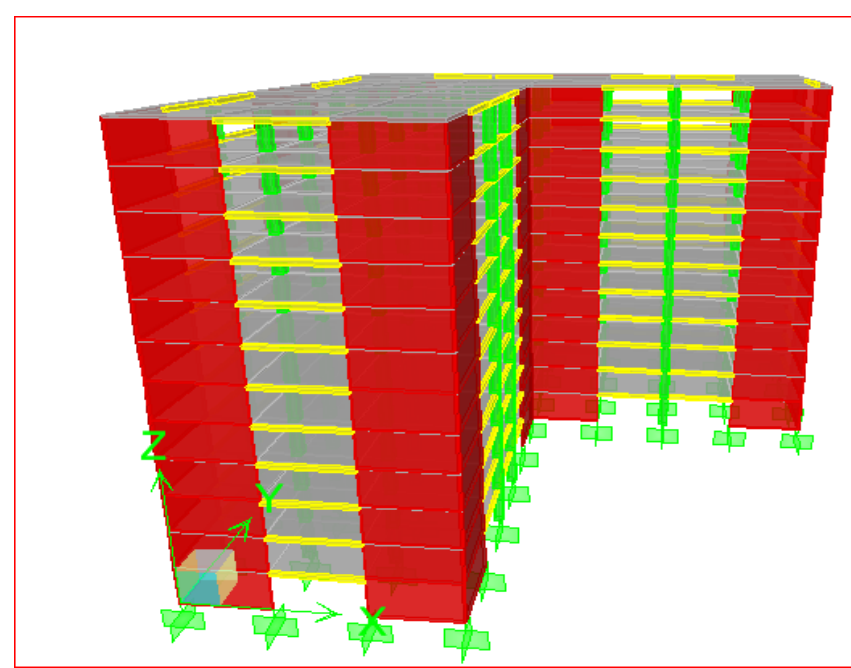

Fig-4: 3D model of flat plate with shear wall

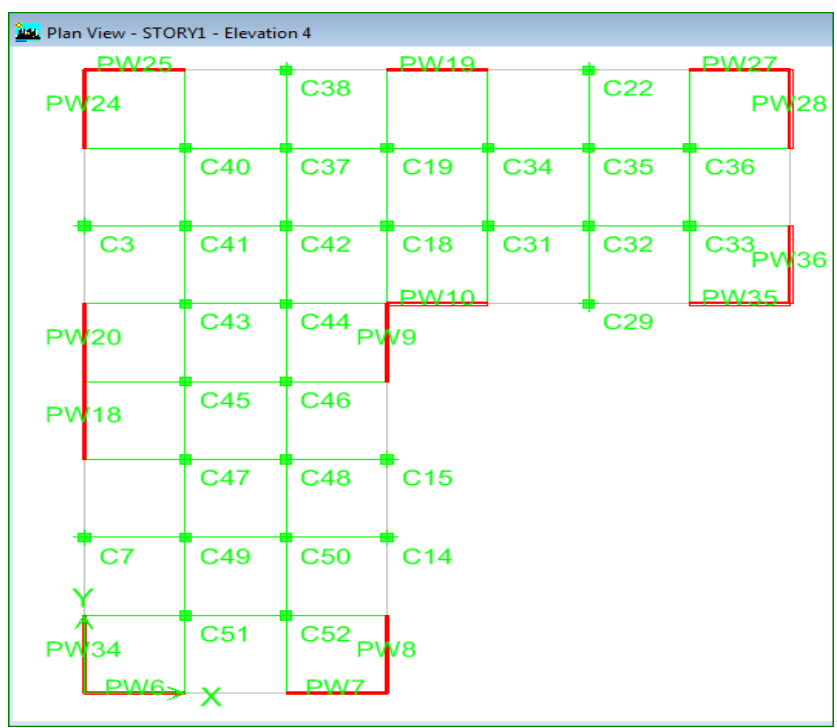

Fig-4: Plan view of flat plate with shear wall

\section{METHODOLOGY}

The models are designed as per Indian standard codes against gravity and earthquake loads. Linear static analysis is performed to obtain the column axial forces to determine the DCR values for both the models for loss of columns at different location on at a time. The objective of this study is DCR calculation of the buildings under column removal cases of the models as per the GSA recommendations. DCR calculations are done by considering the actual capacity of the column and axial force obtained from the progressive collapse analysis as shown below

Axially Loaded column in Compression may be designed by the following equation [13]

$\mathrm{P}_{\mathrm{U}}=\left(0.4 \mathrm{Xf}_{\mathrm{Ck}} \mathrm{XA}_{\mathrm{C}}\right)+\left(0.97 \mathrm{Xf}_{\mathrm{Y}} \mathrm{XA}_{\mathrm{SC}}\right)$
Where,

$\mathrm{Pu}=$ Axial load on the member,

$\mathrm{f}_{\mathrm{Ck}}=$ characteristic compressive strength of the concrete,

Ac $=$ Area of concrete,

$f_{y}=$ characteristic strength of the compression reinforcement, and

$\mathrm{A}_{\mathrm{SC}=}$ area of longitudinal reinforcement for columns.

\subsection{GSA Guidelines}

The General Service Administration (GSA) gives the guidelines for the removal of one column at a time from the storey one above the ground floor. GSA guidelines give criteria for column removal of statically analyzed cases of concrete and steel structures.

According to GSA guidelines, the column can be removed for atypical structure such as exterior column in the middle of longer side of the structure and exterior column in the middle of shorter of the structure.

Acceptance criteria:

$\mathbf{D C R}=\mathbf{Q u}_{\mathrm{D}} / \mathbf{Q}_{\mathrm{CE}}$

where, $\quad$ DCR $=$ Demand Capacity Ratio,

$\mathrm{Q}_{\mathrm{UD}}=$ Acting force (demand) determined in component or connection/joint (moment, axial force, shear, and possible combined forces)

$\mathrm{Q}_{\mathrm{CE}}=$ Expected ultimate/ un-factored capacity of the component and/or connection/joint (moment, axial force, shear and possible combined forces).

The allowable DCR value for primary and secondary structural elements is $<1.5$ for atypical structural configurations, members exceeding this value are considered to be failed [2]. Linear static analysis is conducted for 2 models. Then at certain position of the structure the some columns and shear walls are removed as shown in Table-1 by adopting GSA guidelines. Flat slab analysis and design is done by using SAFE software. To evaluate the process of collapse propagation, first irregular building having flat slab with shear wall and without shear has been analyzed, designed and checked using ETABS, and then the sequence of collapsed elements are investigated one after another to evaluate the progressive collapse distribution. The critical column elements and significant collapse distributions are identified. Then the results are checked from the analysis. After that each individual columns collapse behaviors are checked for DCR.

\subsection{Load Combinations}

The buildings are analyzed and designed as per Indian standard guidelines for Reinforced concrete design.

Load combination for Progressive collapse analysis as per GSA Static analysis.

2DL+0.5LL

Where $\mathrm{DL}=$ dead load

$\mathrm{LL}=$ Live load 
Table-1: Column removal cases

\begin{tabular}{|l|l|l|l|}
\hline \multirow{2}{*}{$\begin{array}{l}\text { Type of } \\
\text { model }\end{array}$} & $\begin{array}{l}\text { Column/shear wall removed at storey } \\
\text { level 2 }\end{array}$ \\
\cline { 2 - 4 } & Case1 & Case2 & Case3 \\
\hline Model-I & C49 & C21 & C17 \\
\hline Model-II & PW18 & PW10 & PW27 \\
\hline
\end{tabular}

The column notations of two models are as shown in Fig-2 and 4 for model 1 and model 2 respectively.

\section{RESULT AND OBSERVATION}

The column DCR values are compiled in Table- 2 and 3 with respect to the graphs for two models. From the obtained results the DCR values are exceeding the limiting value as specified in GSA guidelines up to storey 5 in model I and upto storey 4 in Model II.

There are no columns failing above $5^{\text {th }}$ storey for GSA combination. In model-I at column removal case- 2 and case3 , the obtained DCR is high when compared to column removal case-1. In model-II, the same DCR values are obtained for all three shear wall removal cases. Figure 7 shows the number of columns expected to exceed design capacities and DCR limits the shear wall model has equal distribution and number elements in storey 2 and above.

Table-2: Comparison of maximum DCR values for different cases of Model-I

\begin{tabular}{|l|l|l|l|}
\hline \multirow{2}{*}{ STOREY } & CASE-1 C49 & $\begin{array}{l}\text { CASE-2 } \\
\text { C21 }\end{array}$ & CASE-3 C17 \\
\cline { 2 - 4 } & DCR(C36) & DCR(C34) & DCR(C44) \\
\hline STOREY1 & 2.1689 & 2.439141 & 2.4607 \\
\hline STOREY2 & 1.979013 & 2.261153 & 2.88964 \\
\hline STOREY3 & 1.793032 & 2.043427 & 2.06602 \\
\hline STOREY4 & 1.608473 & 1.828835 & 1.847369 \\
\hline STOREY5 & 1.425201 & 1.617231 & 1.632269 \\
\hline STOREY6 & 1.243054 & 1.408173 & 1.420288 \\
\hline STOREY7 & 1.061883 & 1.201311 & 1.21096 \\
\hline STOREY8 & 0.88154 & 0.996292 & 1.003864 \\
\hline STOREY9 & 0.701879 & 0.79279 & 0.798592 \\
\hline STOREY10 & 0.522763 & 0.590485 & 0.59476 \\
\hline STOREY11 & 0.344023 & 0.389062 & 0.391982 \\
\hline STOREY12 & 0.165663 & 0.188242 & 0.189968 \\
\hline
\end{tabular}

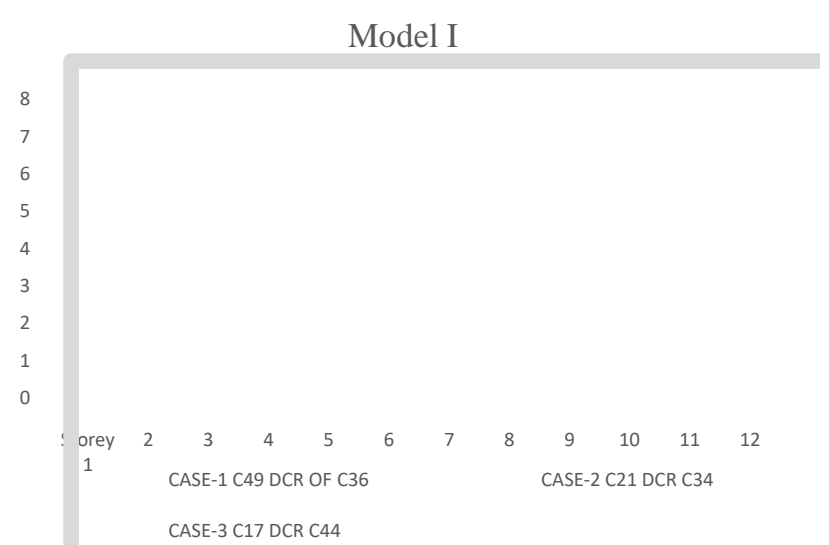

Chart 1: DCR comparison for 3 column removal cases of model-I for GSA combination

Table-3: Comparison of maximum DCR values for different cases of model-II

\begin{tabular}{|l|l|l|l|}
\hline \multirow{2}{*}{ STOREY } & $\begin{array}{l}\text { CASE-1 } \\
\text { SW27 }\end{array}$ & $\begin{array}{l}\text { CASE-2 } \\
\text { SW10 }\end{array}$ & $\begin{array}{l}\text { CASE-3 } \\
\text { SW18 }\end{array}$ \\
\cline { 2 - 4 } & DCR(C36) & $\begin{array}{l}\text { DCR(C5 } \\
\text { 1) }\end{array}$ & DCR(C36) \\
\hline STOREY1 & 2.28072 & 2.281578 & 2.313612 \\
\hline STOREY2 & 2.079312 & 2.08013 & 2.113166 \\
\hline STOREY3 & 1.882313 & 1.883092 & 1.911703 \\
\hline STOREY4 & 1.687259 & 1.68799 & 1.713043 \\
\hline STOREY5 & 1.493923 & 1.494585 & 1.516449 \\
\hline STOREY6 & 1.302128 & 1.302716 & 1.321587 \\
\hline STOREY7 & 1.111674 & 1.112182 & 1.128181 \\
\hline STOREY8 & 0.922362 & 0.922787 & 0.936001 \\
\hline STOREY9 & 0.73399 & 0.734332 & 0.744828 \\
\hline $\begin{array}{l}\text { STOREY1 } \\
0\end{array}$ & 0.546369 & 0.546626 & 0.554454 \\
\hline $\begin{array}{l}\text { STOREY1 } \\
1\end{array}$ & 0.359289 & 0.359462 & 0.36466 \\
\hline $\begin{array}{l}\text { STOREY1 } \\
2\end{array}$ & 0.172588 & 0.172675 & 0.175268 \\
\hline
\end{tabular}

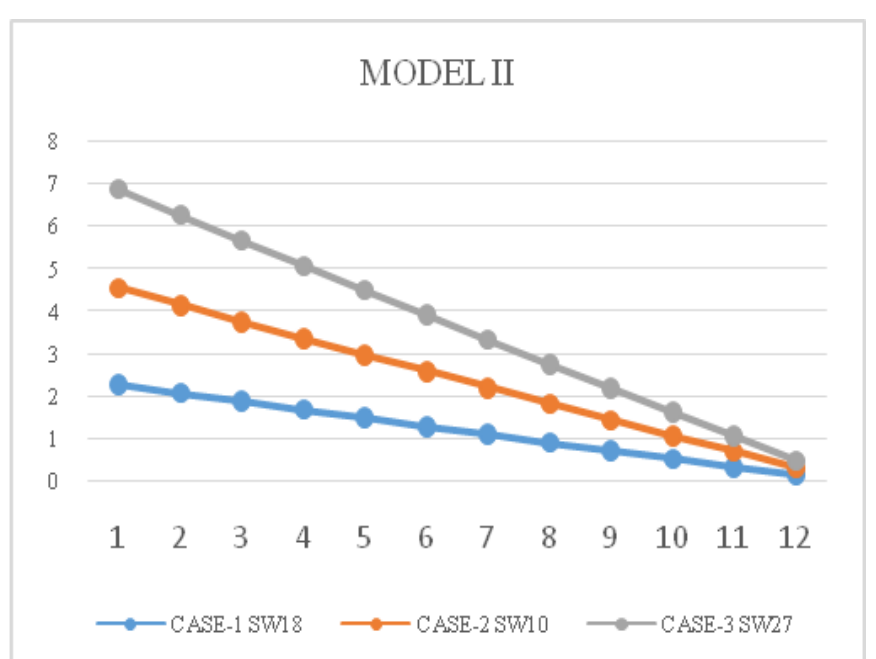

Chart 3: DCR comparison for 3 column removal cases of Model-II for GSA combination 
Table-4: Comparison of number of columns exceeding DCR limiting value for GSA combination

\begin{tabular}{|l|l|l|l|l|l|l|}
\hline \multirow{2}{*}{ STOREY } & \multicolumn{4}{|l}{ MODEL-I } & \multicolumn{3}{l|}{ MODEL-II } \\
\cline { 2 - 7 } & C-1 & C-2 & C-3 & C-1 & C-2 & C-3 \\
\hline STOREY1 & 23 & 25 & 24 & 22 & 22 & 22 \\
\hline STOREY2 & 22 & 24 & 22 & 22 & 22 & 22 \\
\hline STOREY3 & 22 & 22 & 22 & 22 & 22 & 22 \\
\hline STOREY4 & 22 & 22 & 22 & 22 & 22 & 22 \\
\hline STOREY5 & 0 & 1 & 2 & 0 & 0 & 0 \\
\hline
\end{tabular}

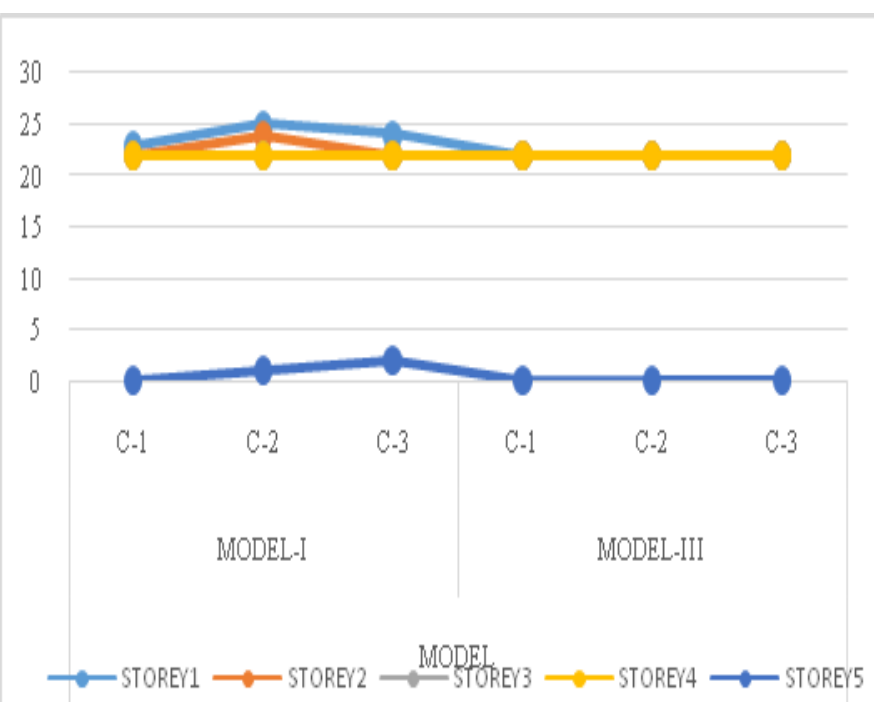

Chart 2: Comparison of number of columns exceeding DCR limiting value in 2 models.

Table-5: Storey variation of maximum DCR elements in common position in plan for both models.

\begin{tabular}{|l|l|l|}
\hline \multirow{2}{*}{ STOREY } & CASE-3 C17 & CASE-2 SW10 \\
\cline { 2 - 3 } & DCR C44 & DCR OF C51 \\
\hline 1 & 2.4607 & 2.281578 \\
\hline 2 & 2.88964 & 2.08013 \\
\hline 3 & 2.06602 & 1.883092 \\
\hline 4 & 1.847369 & 1.68799 \\
\hline 5 & 1.632269 & 1.494585 \\
\hline 6 & 1.420288 & 1.302716 \\
\hline 7 & 1.21096 & 1.112182 \\
\hline 8 & 1.003864 & 0.922787 \\
\hline 9 & 0.798592 & 0.734332 \\
\hline 10 & 0.59476 & 0.546626 \\
\hline 11 & 0.391982 & 0.359462 \\
\hline 12 & 0.189968 & 0.172675 \\
\hline
\end{tabular}

\section{COMPARISON OF MAXIMUMDCR of elements in same position}

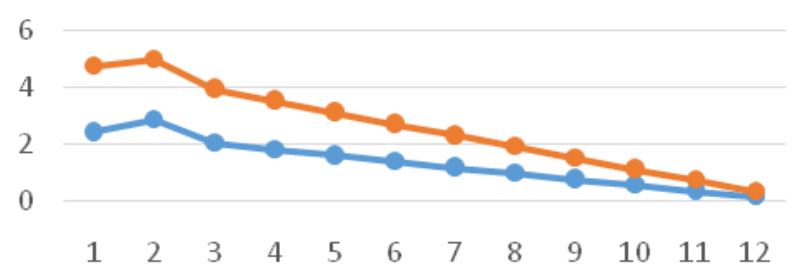

$\longrightarrow$ CASE-3C17 $\longrightarrow$ CASE-2 SW10

Chart 4: Comparison of DCR values of structural elements in same position in plan over storey

\section{CONCLUSION}

From the study progressive collapse potential evaluated for two models indicates that the building with shear wall and building without shear wall indicates a complete collapse due to column and shear wall removal for all cases.

which indicates dead weights of higher storeys leads to further collapse by impact. There is a clear understanding that the shear wall buildings provide additional vertical stiffness and uniform load paths compared to normal flat slab building. Future scope indicates a nonlinear analysis can yield a better understanding of collapse mechanism in the structure.

\section{REFERENCES}

[1]. General Service Administration. "Progressive Collapse Analysis and Design Guidelines for New Federal Office Buildings and Major Modernization Projects", June 2003.

[2]. B. Gururaja, R. Sridhar. "Progressive Collapse Potential of Irregular Concrete Building". International Conference on Advances in Engineering \& Technology - 2014 (ICAET-2014).

[3]. Rizwan Bhina, D. K. Paul, Arnab Banerjee. "Assessment of different aspects of R.C flat slab building over normal R. C. frame building". December2013.

[4]. Sanjay P. N, Mahesh Prabhu K, Umash S.S. "Behavior of flat slab RCC structure under earthquake loading". International journal of research in Engineering and Technology (IJERT) Vol.3 Issue 5, May-2014.

[5]. R.S.More, V. S. Sawant, Y. R. Suryawanshi. "Analytical study of different types of flat slab subjected to dynamic loading". International Journal of Science and Research (IJSR) ISSN (Online): 23197064 Index Copernicus Value (2013): 6.14 | Impact Factor (2013): 4.438

[6]. Rajiv M S, Guru Prasad T N, Dharmesh N, Madhusudhana Y B."Seismic behaviour of multistoreyed RC building having flat slab with and without shear walls". International journal of scientific engineering and technology research (IJSETR). Vol.04, Issue.29, August-2015. 
[7]. Saraswathi Setia, Shakti Kalyni. "Seismic behavior of connections subjected to punching shear in flat-slab systems". December 31, 2015.

[8]. Seweryn Kokot, Armelle Anthoine, Paolo Negro, George Solomos."Static and dynamic analysis of a reinforced concrete flat slab frame building for progressive collapse”. ELSEVIER. March 28, 2012.

[9]. M Vinod Kumar Reddy, Dr. Vaishali G Ghorpade. "Comparative study of seismic analysis between conventional and flat slab with drop and without drop framed structures with different masonry infills". International journal of engineering research and technology (IJERT). Vol.3, Issue10, October-2014.

[10]. N.Krishnaraju, "Design of Reinforced Concrete Structures", CBS Publication $3^{\text {rd }}$ edition, 2003.

[11]. IS456: 2000 code of practice for plain \& reinforced concrete, fourth revision.

[12]. IS875 (PART- I): 1987 code of practice for design loads (other than earthquake) for buildings and structures part I dead loads.

[13]. IS875 (PART -II): 1987 code of practice for design loads (other than earthquake) for buildings and structures part II imposed loads.

[14]. IS: 1893 part 1 - 2002: Criteria for earthquake resistant design of structures (part-1 general provisions and buildings).

\section{BIOGRAPHIES}

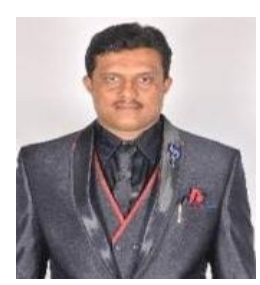

Gururaja B was born in India in 1987.

$\mathrm{He}$ received the B.E., and M.Tech.Degrees from VTU, Belgaum, India, in 2010 and 2013, respectively.He joined SJBIT as in 2014. His main areas of research interest are Progressive collapse, Wind analysis and Bacterial concrete.He is member of ASCE, IAENG and SEFI

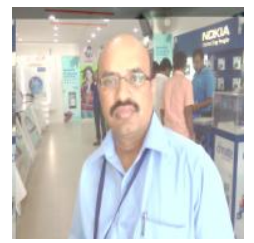

R.Sridhar,Sr.Assoc.Professor,Dept. of Civil Engg.Nagarjuna college of Engg. \& Technology. Fellow member of ACCE 